\title{
On the interest of using field primary production data to calibrate phytoplankton rate processes in ecosystem models
}

\author{
Karine Grangeré ${ }^{a, b,{ }^{*}}$, Sébastien Lefebvre ${ }^{b}$, Alain Ménesguen ${ }^{a}$ and Fabien Jouenne ${ }^{c}$
}

\begin{abstract}
a IFREMER, Département Dynamique de l'Environnement Côtier, Technopôle Brest-Iroise, z.i. Pointe du diable, B.P. 70, 29280 Plouzané, France

b UMR 100 IFREMER-UCBN PE2M Physiologie et Ecophysiologie des Mollusques Marins, Laboratoire de Biologie et Biotechnologies Marines, Université de Caen Basse-Normandie, Esplanade de la Paix, 14032 Caen Cedex, France

c Station Biologique de Roscoff, UMR 7144, CNRS \& UPMC, Place Georges Teissier, BP 74, 29682 Roscoff Cedex, France
\end{abstract}

*: Corresponding author : K. Grangeré, email address : karine.grangere@hotmail.fr

\begin{abstract}
:
In many ecosystem models based on empirical formulations, parameters generally are calibrated in order to achieve the best fit between measured and simulated chlorophyll a standing stocks. An accurate calibration of rate processes as primary production rarely is taken into account. In this paper, we test the usefulness of calibration of phytoplankton photosynthetic processes in an ecosystem model using field primary production data. We used 18 months of photosynthetic process data from the Baie des Veys ecosystem (Normandy, France). Five empirical formulations of photosynthesisirradiance curve models amongst the most widely used were tested. In each formulation, the variability of photosynthetic parameters (i.e. the light-saturated rate of photosynthesis $\left(P_{\max }{ }^{\mathrm{B}}\right)$ and the initial slope of the photosynthesis-light curve $\left(a^{\mathrm{B}}\right)$ ) was considered depending on environmental factors (temperature and nutrient availability). The fit of the five equations as well as the calibration of parameters on field measurements (i.e. the light-saturated rate of photosynthesis $\left(P_{\text {ref }}{ }^{\mathrm{B}}\right)$, the initial slope of the photosynthesis-light curve $\left(\alpha_{\text {ref }}{ }^{\mathrm{B}}\right)$, the half-saturation constant for nitrogen $\left(K_{\mathrm{N}}\right)$ and silicates uptake $\left(K_{\mathrm{Si}}\right)$, and the coefficient in the exponential thermal effect $\left.\left(K_{\mathrm{T}}\right)\right)$ was performed using the whole available data set of $P$ vs. $E$ curves ( $n=143, P$ vs. $E$ curves). Then, the Smith formulation allowing the best simulation of the Baie des Veys primary production and corresponding parameters were introduced in an ecosystem box model. This formulation led directly to a satisfactory representation of the Baie des Veys phytoplankton dynamics without additional calibration. Results obtained were compared with a more classical approach in which ecosystem models were calibrated using published values of parameters. This comparison showed that for the two years studied, annual primary production estimated through the ecosystem model was $13 \%$ and $26 \%$ higher with our approach than with the more classical approach. This work emphasizes the importance of accurately representing rate processes in ecosystem models in order to adequately simulate production as well as standing stocks.
\end{abstract}

Keywords: photosynthesis-irradiance curve; empirical formulations; mechanistic formulations; parameter optimisation; chlorophyll a to carbon ratio; diatoms; France; Normandy; Baie des Veys 


\section{Introduction}

Dynamic simulation models are commonly used to study ecosystem functioning (e.g. Fasham et al., 1990; Baretta et al., 1994; Ménesguen and Hoch, 1997; Baklouti et al., 2006a). Outputs of ecosystem models depend mainly on the formulation of the biogeochemical processes. However, lack of knowledge about underlying mechanisms usually leads to an empirical description of phytoplankton production processes. An adequate description of phytoplankton dynamics is essential because phytoplankton forms the base of the open water food web. Different empirical formulations of the same processes are usually found in the literature. For example, some typical formulations of the effect of light limitation on growth rate are provided by Webb et al. (1974), Platt et al. (1975), and Steele (1962). The latter is commonly used in ecosystem models (Ebenhöh et al., 1997).

In order to estimate an adequate set of parameters to calibrate an empirical relationship, it is necessary to conduct extensive field experiments and laboratory measurements on the process under study. Thus, a major deficiency of this strategy is that it requires a sizeable sampling effort on the ecosystem studied, because it is difficult to extrapolate parameters estimated for a given ecosystem to other ecosystems with different functioning (Baird et al., 2003). Consequently, for each empirical relationship, a wide range of parameter values exist in the literature. For example, numerous published values of the half-saturation constant for nitrogen uptake range from 0.02 to $10.2 \mu \mathrm{mol} \mathrm{N}{ }^{-1}$ (Sarthou et al., 2005). An alternative solution is to introduce a mechanistic model of phytoplankton physiology in biogeochemical models. Mechanistic relationships describe the fundamental dynamic laws involved in photosynthesis, nutrient uptake, and protein synthesis; therefore, these models are based on biochemical knowledge. This approach has the advantage of reducing the need for extrapolation of model parameters (Baklouti et al., 2006b). Phytoplankton mechanistic models are not usually used in ecosystem models, however, because these complex processes are more difficult to calibrate and markedly increase computational time (Flynn, 2003b).

In most ecosystem models, calibration is generally performed on standing stocks (phytoplankton biomass) rather than rate processes (primary production) (Brush et al., 2002). This is mainly due to the lack of data in many ecosystem studies. Thus, an adequate fit of a simple model to existent data sets of biomass does not guarantee that its behaviour is reliable under other conditions (Flynn, 2003b). Furthermore, if rate processes are not reproduced adequately, the fit obtained between model and measurements could result from parameter 
adjustment during calibration more than model dynamics. Phytoplankton biomass is directly related to other components of the ecosystem, such as dissolved nutrients or predators (zooplankton, suspension-feeders), and therefore has a direct influence on the dynamics of the whole ecosystem. Brush et al. (2002) argue that to reproduce ecosystem dynamics, it is of critical importance to accurately simulate rate processes as well as values of state variables. According to Lawson et al. (1996), accurate estimation of rate processes in models of phytoplankton production involves data availability at 2-week intervals. That condition is rarely met for marine systems (Flynn, 2003b).

Photosynthetic processes have been extensively studied in laboratory experiments in order to better understand the underlying mechanisms. The response of photosynthesis to irradiance is commonly modelled as a photosynthesis-irradiance ( $\mathrm{P}$ vs $\mathrm{E}$ ) response curve (Jassby and Platt, 1976; Sakshaug et al., 1997), which describes the specific photosynthetic rate as a saturating function of irradiance (Geider et al., 1997). Numerous studies describe the mechanistic bases of the P vs E relationship (e.g. Geider et al., 1997; Baklouti et al., 2006b). Two parameters describe the response of photosynthesis to irradiance: $\mathrm{P}^{\mathrm{B}}$ max , the maximum photosynthetic rate and $\alpha^{\mathrm{B}}$, the maximum light utilization coefficient. Relatively few ecosystem models introduced explicitly the P vs E relationship, even though this is the process measured experimentally, mainly due to the lack of data for calibration and validation (Flynn, 2003a). Indeed, most field studies on primary production were undertaken to understand ecosystem function, not to acquire data for parameterization of a primary production model.

Another limitation to the use of photosynthetic processes in ecosystem models is that phytoplankton productivity usually is measured as carbon assimilation rate, while biomass is often measured as chlorophyll $a$ concentration because it is the most widely-used index of phytoplankton abundance in oceans (Geider, 1987; Geider et al., 1997; Flynn, 2003b). In phytoplankton models, growth rate usually is considered to be a function of light, nutrients, and temperature. Transformation of productivity and biomass into population growth rate requires a conversion factor between these different units of measurement, specifically, the cellular ratio of chlorophyll $a$ to carbon: Chl $a$ :C (Cloern et al., 1995). In many ecological studies on phytoplankton, the $\mathrm{Chl} a$ :C ratio has been assumed to be a constant, even if this is far from the observed reality (Geider et al., 1997). Classical values used in these studies are those suggested by Strickland (1960), $0.03 \mathrm{~g} \mathrm{Chl} a: \mathrm{g} \mathrm{C}^{-1}$ for nutrient-rich waters and $0.016 \mathrm{~g}$ Chl $a$ :g $\mathrm{C}^{-1}$ for nutrient-poor waters; however, constant fluctuations in cellular chlorophyll quotas prevent use of a simple conversion from chlorophyll to biomass (Flynn, 2003b; 
Baklouti et al., 2006b), which varies from 0.003 to $>0.1 \mathrm{~g}$ Chl $a$ :g $\mathrm{C}^{-1}$ in phytoplankton cultures (Geider, 1987) and is expected to vary equally in nature (Geider et al., 1997). The Chl $a$ :C ratio does not vary randomly. It is highly responsive to irradiance, nutrient availability, and temperature (Geider, 1987; Cloern et al., 1995; Geider et al., 1998). Thus, adequate accounting for changing $\mathrm{Chl} a$ :C ratios in models is important in order to accurately simulate phytoplankton dynamics as a function of external forcing functions like irradiance, nutrients, and temperature.

The main objective of the present paper was to improve the simulation of primary production processes in ecosystem models using photosynthetic parameters calibrated on field measurements. First, an empirical model of P vs E curve was selected and calibrated using a comprehensive field data set of photosynthetic parameters acquired over 18 months. Second, calibrated rate-process parameters of the P vs E curve model were introduced in an ecosystem model in order to simulate phytoplankton production as well as chlorophyll $a$ standing stock. Finally, the results of our approach were compared with simulations obtained using a more classical approach based on parameters obtained from the literature.

\section{Methods}

\subsection{Study site}

The Baie des Veys estuary is located in the north of France in the western part of the Baie de Seine in Normandy (Fig. 1). It is a macrotidal estuary, with a maximal tidal range of 8 $\mathrm{m}$ and a small intertidal area of $37 \mathrm{~km}^{2}$ (Desprez et al., 1986). Freshwater enters the southern part of the bay from four rivers that drain a catchment (watershed) basin of 3,500 $\mathrm{km}^{2}$. The main river, the Vire, has an annual mean discharge of $20 \mathrm{~m}^{3} \mathrm{~s}^{-1}$. The main source of nutrients in the bay comes from the rivers. These inputs induce high primary production during spring, with diatoms predominating (Jouenne et al., 2007).

\subsection{Data set}

Available data came from a study conducted between May 2002 and October 2003 in the Baie des Veys (Jouenne et al., 2007). In that study, samples were collected fortnightly at five stations (four located in the bay and one in the estuary, Fig. 1) and at two depths at each station: surface and the depth having $20 \%$ of the incident light intensity. Measured parameters 
were Chl $a$ concentration $\left(\mathrm{B}^{\mathrm{Chl} a}\right)$, temperature $(\mathrm{T})$, light, and nutrients (dissolved inorganic nitrogen $(\mathrm{N})$, silicate $(\mathrm{Si})$, phosphate $(\mathrm{P})$ ) and the light attenuation coefficient $(\mathrm{k})$. Photosynthesis light curves (hereafter $\mathrm{P}$ vs $\mathrm{E}$ curves), based on ${ }^{14} \mathrm{C}$ incubations, were measured for each sample ( $\mathrm{n}=143)$. Additional details of the data are in Jouenne et al. (2007).

\subsection{Comparison of $P$ vs E curve models and processes calibration}

The functions describing control of photosynthesis by light generally are defined to reproduce the usual shape of the experimental P vs E curve, which implies that it must have zero primary production at zero irradiance (Baklouti et al., 2006b). Five formulations were selected among the most widely-used expressions for the light-saturation functions (Table 1). According to Jassby and Platt (1976), these formulations all are described in terms of $\alpha^{\mathrm{B}}$ and $\mathrm{P}^{\mathrm{B}}{ }_{\max }$, which represent the maximum light utilization coefficient and the maximum photosynthetic rate, respectively. Therefore, all equations are presented in equivalent form and may legitimately be compared with respect to their success in fitting the experimental data (Jassby and Platt, 1976). In the five formulations tested the influence of factors such as temperature and nutrients can be represented mathematically through their effect on the photosynthetic parameters, $\alpha^{\mathrm{B}}$ and $\mathrm{P}^{\mathrm{B}}{ }_{\max }$ (Jassby and Platt, 1976). According to Geider et al. (1997), nutrient-limitation and temperature affect phytoplankton physiology by imposing a limit on the light-saturated photosynthesis rate. Thus, $\mathrm{P}_{\text {max }}^{\mathrm{B}}$ is considered to be a multiplicative function of temperature and nutrient availability (Eq. 6, Table 2). The nutrientlimitation of $\mathrm{P}^{\mathrm{B}}{ }_{\text {max }}$ was represented with Monod's (1949) equation, which implies that $\mathrm{P}^{\mathrm{B}}$ max depends only on the external nutrient concentration. In this study, only nutrients that imply a growth limitation were considered, nitrogen (N) and silicates (Si) (Jouenne et al., 2007). At each time-step, the lowest of the calculated nutrient limitation factors was used. The effect of temperature on $\mathrm{P}^{\mathrm{B}}{ }_{\max }$ was described with a $\mathrm{Q}_{10}$ law (Eppley, 1972). Geider et al. (1997) and Behrenfeld et al. (2004) suggest that the initial slope of the P vs E curve may be variable depending on variations of environmental conditions. Therefore, as for $\mathrm{P}_{\max }^{\mathrm{B}}, \alpha^{\mathrm{B}}$ was described as a multiplicative function of temperature and nutrient-limitation (Eq. 7, Table 2).

The fit of the five equations as well as the calibration of parameters (i.e. the lightsaturated rate of photosynthesis $\left(\mathrm{P}^{\mathrm{B}}\right.$ ref $)$, the initial slope of the photosynthesis-light curve $\left(\alpha_{\text {ref }}^{\mathrm{B}}\right)$, the half-saturation constant for nitrogen $\left(\mathrm{K}_{\mathrm{N}}\right)$ and silicates uptake $\left(\mathrm{K}_{\mathrm{Si}}\right)$ and the coefficient in the exponential thermal effect $\left(\mathrm{K}_{\mathrm{T}}\right)$ ) on field measurements was performed 
using all available data at every stations and at every dates. The fit of P vs E curve against field $\mathrm{P}$ vs E measurements was carried out using a nonlinear optimisation algorithm, the simplex method (Nelder and Mead, 1965). The convergence test aimed at minimizes the sum of the squared residuals. Initial conditions for parameters were chosen randomly and the optimisation procedure was run 100 times to get the best fit and to avoid local minima. A bootstrap method was applied 500 times in order to evaluate the variability of estimated parameter values. Simple linear regressions were used to estimate the quality of the parameter optimisation and to quantify the relationships between the measured and simulated P vs E curves as well as between the measured and simulated Chl $a$ standing stocks. The goodnessof-fit was tested according to the determination coefficient of the regression $Y=a X+b$ as suggested by Mesplé et al. (1996), where values of X are observed values and values of $\mathrm{Y}$ are predicted ones.

\subsection{Application in the ecosystem model}

The best one of the five tested $\mathrm{P}$ vs $\mathrm{E}$ curve models (see $\S 2.3$ ) and estimated parameters from field measurements was implemented in an ecosystem model. The simulation obtained was compared with a more classical approach using parameters based on published values and a validation performed on standing stocks. In order to clarify the comparison, the former simulation was called the "process simulation" and the latter was called the "reference simulation" throughout the paper.

The physical sub-model is a box model without spatial discretisation. The theoretical position of the box is indicated on Fig. 1. The box corresponds to the mean features of the area under study. The surface is $50 \mathrm{~km}^{2}$, the depth is $5 \mathrm{~m}$ and the average residence time is 5 days (Grangeré, unpublished data). In the Baie des Veys ecosystem no significant spatial differences was highlighted in the dynamic of the main state variables (i.e. chlorophyll $a$, nutrient concentrations) (Jouenne, unpublished data). Thus, the use of a single box model allowed to simulate the average pattern of the main state variables in the modelled domain.

The biogeochemical model used in this study was developed by Ménesguen and Hoch (1997), Guillaud et al. (2000), and Ménesguen et al. (2007). It is a classical NPZD model (Nutrients, Phytoplankton, Zooplankton, and Detritus) expressed in nitrogen units. The model has 11 state variables and its conceptual structure is presented in Fig. 2. All formulations and parameters for phytoplankton growth used in the "process simulation" and in the "reference simulation" are indicated in Table 2. All other state variable equations and parameters used in 
this study are the same than in Guillaud et al. (2000). We decided to use this ecosystem model, because it was implemented in the Baie de Seine which is close to the Baie des Veys.

In the "process simulation”, the Smith's model and corresponding parameters were used (see $\S 2.3$., Table 2 and result section $\S 3.1$.). The introduction of photosynthetic processes estimated from field measurements in an ecosystem model needs the use of a conversion factor between primary production $\left(\mathrm{P}^{\mathrm{B}}\right)$ and growth rate $(\mu)$ : the chlorophyll $a$ to carbon ratio (Chl a:C) (Eq. 11, Table 2). Two approaches were tested, in a first attempt, a

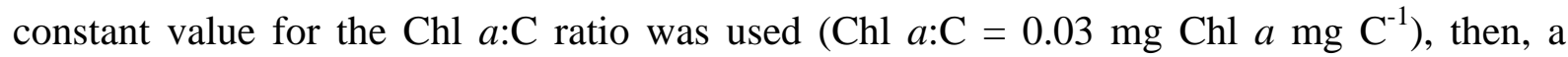
variable Chl $a$ :C ratio was implemented. Different ways are used to introduce a variable Chl $a: C$ ratio in biogeochemical models, from basic empirical correlations (Cloern et al., 1995) to analytical formulations based on underlying mechanisms (Geider et al., 1996, 1998). Multinutrient models based on an empirically-derived $\mathrm{Chl} a$ :C ratio should be adequate in models for most oceanographic modelling scenarios (Flynn, 2003b); therefore, the empirical formulation of the Chl $a$ :C ratio proposed by Cloern et al. (1995) was used:

$$
\text { Chla: } C=0.003+0.0154 \exp (0.050 T) \exp (-0.059 E) \min \left(f_{N}, f_{S i}\right)
$$

where $\mathrm{T}$ is the temperature $\left({ }^{\circ} \mathrm{C}\right), f_{\mathrm{N}}$ and $f_{\mathrm{Si}}$ are the nitrogen and silicate limitation respectively (Eq. 9, for values see Table 2). $E$ is the daily irradiance $\left(\mathrm{E} \mathrm{m}^{-2} \mathrm{~d}^{-1}\right)$ averaged over the depth of the mixed layer $(\mathrm{H})$ as follows:

$$
E=\left(\frac{E_{0}}{k H}\right)[1-\exp (-k H)]
$$

where $E_{0}\left(\mathrm{E} \mathrm{m}^{-2} \mathrm{~d}^{-1}\right)$ is daily irradiance just below the surface and $\mathrm{H}$ is the mean depth of the Baie des Veys water column, $\mathrm{H}=5 \mathrm{~m}, \mathrm{k}\left(\mathrm{m}^{-1}\right)$ is the spectrally averaged light attenuation coefficient.

In the "reference simulation", the only difference between equations used in this study and those published by Guillaud et al. (2000) is the formulation of the light limitation on phytoplankton growth. According to results obtained in the section on the comparison of primary production equations (see $\S 4.1$.), we decided to implemented Smith’s equation instead of Steele's as used by Guillaud et al. (2000) (Table 2). The influence of nutrient limitation was also described using Monod's formulation, considering nitrogen and silicate. Temperature effect is also described using the $\mathrm{Q}_{10}$ law. Growth rate was expressed using a threshold approach depending on the most limiting function between light limitation and nutrient limitation (Liebig's law, Eq. 12, Table 2). Parameter used for primary production are the same than those used in Guillaud et al. (2000) and came from published values (Table 2). 
In their study, validation of the biogeochemical model was performed by estimating the general standard deviation between simulated and observed standing stocks (i.e. chlorophyll $a$ and nutrients).

Two boundaries were considered: the northern one receives inputs from the Baie de Seine, whereas the southern one receives inputs from the rivers. Landward boundary conditions were derived from measurements in the four tributaries. Nutrients (inorganic nitrogen and silicate) were measured monthly by the "Agence de l'eau Seine-Normandie”, and river discharges were measured daily by the "DIrection Régional de l'ENvironnement (DIREN)". Seaward boundary conditions for nutrients and organic matter came from outputs of the three-dimensional model of the Baie de Seine developed by Cugier et al. (2005). A constant value of $0.5 \mu \mathrm{mol} \mathrm{N}{ }^{-1}$ corresponding to average winter concentrations was imposed as the boundary condition for diatom biomass in order to ensure that the phytoplankton dynamics simulated by the box model resulted from the internal functioning rather than dynamics forced by the boundary conditions.

\section{Results}

\subsection{Comparison of primary production models and processes calibration}

The fit of the five formulations tested was performed for the whole available data set of $\mathrm{P}$ vs $\mathrm{E}$ curves. For each formulation a linear regression was performed between measured and simulated primary production. The estimation of determination coefficients displayed in Table 1 indicates that the best fits of the primary production equations to the $\mathrm{P}$ vs $\mathrm{E}$ curves were obtained with the formulations of Webb et al. (1974), Platt et al., (1975), and Smith (1936). Conversely, the worst fits were given by Monod's (1950) and Steele's (1962) equations. The modelled P vs E curves displayed in Fig. 3 were chosen in order to illustrate the fit of the five formulations against an example of field $\mathrm{P}$ vs E curve. As a whole, results showed an adequate fit for Webb et al., Platt et al. and Smith equations. In contrast, at

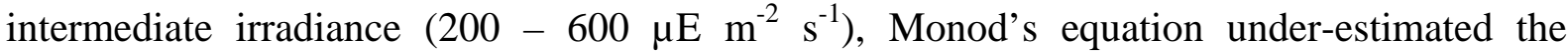
production, whereas at high irradiance $\left(>800 \mu \mathrm{E} \mathrm{m}^{-2} \mathrm{~s}^{-1}\right)$, it reached its plateau too slowly (Fig. 3). Similarly, Steele’s curve under-estimated production at low irradiance $\left(<300 \mu \mathrm{E} \mathrm{m}{ }^{-2}\right.$ $\mathrm{s}^{-1}$ ), over-estimated production between 300 and $800 \mu \mathrm{E} \mathrm{m} \mathrm{m}^{-2} \mathrm{~s}^{-1}$, and showed decreased production at high irradiance (> $800 \mu \mathrm{E} \mathrm{m}^{-2} \mathrm{~s}^{-1}$ ) corresponding to photoinhibition (Fig. 3). In 
this example, the maximum photosynthetic rate $\left(\mathrm{P}^{\mathrm{B}}{ }_{\max }\right)$ was similar for the Webb et al., Platt et al., and Smith equations (ca. $1.22 \mathrm{mg} \mathrm{C} \mathrm{mg} \mathrm{Chl} a^{-1} \mathrm{~h}^{-1}$ ), whereas it was higher for the Monod and Steele equations (ca. 1.33 and $1.46 \mathrm{mg} \mathrm{C} \mathrm{mg} \mathrm{Chl} a^{-1} \mathrm{~h}^{-1}$ respectively, Fig. 3). The maximum light utilization coefficient $\left(\alpha^{\mathrm{B}}\right)$ showed that extreme values always were obtained for the Steele and Monod equations, ca. 0.0024 and 0.0198 (mg C mg Chl $a^{-1} \mathrm{~h}^{-1}\left(\mu \mathrm{E} \mathrm{m} \mathrm{m}^{-2}\right)^{-1}$ $\left.{ }^{1}\right)$ respectively against ca. $0.0122\left(\mathrm{mg} \mathrm{C} \mathrm{mg} \mathrm{Chl} a^{-1} \mathrm{~h}^{-1}\left(\mu \mathrm{E} \mathrm{m} \mathrm{m}^{-2} \mathrm{~s}^{-1}\right)\right.$ for the Webb et al., Platt et al., and Smith equations. As a whole these results are in accordance with the trend obtained when fitted formulations against the whole data set (see determination coefficients, Table 1). The correlation between measured and simulated production was presented for the optimisation performed using Smith's equation (Fig. 4). Results showed a good agreement between measured and simulated production for the low production value, whereas, the highest measured production was not well simulated $\left(\mathrm{P}^{\mathrm{B}}>6 \mathrm{mg} \mathrm{C} \mathrm{mg} \mathrm{Chl} a^{-1} \mathrm{~h}^{-1}\right)$. The same trends were obtained for the other P vs E formulations (data not shown).

In order to highlight when discrepancies occurred, temporal variations of predicted $\mathrm{P}^{\mathrm{B}}{ }_{\max }$ and $\alpha^{\mathrm{B}}$ were calculated according to equations 6 and 7 (Table 2) date by date using calibrated rate-process parameters (Table 2) and field measurements of nutrients ( $\mathrm{N}$ and $\mathrm{Si}$ ) and temperature $(\mathrm{T})$. Predicted $\mathrm{P}^{\mathrm{B}}{ }_{\text {max }}$ and $\alpha^{\mathrm{B}}$ were compared with observed $\mathrm{P}^{\mathrm{B}}{ }_{\max }$ and $\alpha^{\mathrm{B}}$ extracted from field P vs E curves using the basic Smith's model. Good agreement occurred between observed and predicted $\mathrm{P}^{\mathrm{B}}$ max and $\alpha^{\mathrm{B}}$. The seasonal trends of both observed and predicted $\mathrm{P}^{\mathrm{B}}{ }_{\max }$ and $\alpha^{\mathrm{B}}$ were similar, with maxima in summer and minima in winter; however, some discrepancies were obtained mainly during summer when rates of production were the highest (Figs. 5 a and b, respectively). At this period, the simulation under-estimated observed $\mathrm{P}^{\mathrm{B}}$ max and $\alpha^{\mathrm{B}}$.

\subsection{Application of the primary production model and parameters in the ecosystem model}

Application of the Chl $a$ :C ratio formulation developed by Cloern et al. (1995) to the data set measured in the Baie des Veys showed the variability of the $\mathrm{Chl} a: \mathrm{C}$ ratio over the sampling period (Fig. 6). Significant differences were highlighted between bay stations and estuary stations. In the estuary, the $\mathrm{Chl} a$ :C ratio ranged from 0.025 to $0.04 \mathrm{mg} \mathrm{Chl} a \mathrm{mg} \mathrm{C}^{-1}$, whereas the ratio had a greater range in the bay, from 0.005 to $0.03 \mathrm{mg} \mathrm{Chl} a \mathrm{mg} \mathrm{C}^{-1}$. In the bay, maximal Chl $a$ :C ratios occurred in spring and summer and minimal values in autumn and winter, whereas in the estuary, the opposite pattern was highlighted. The estimated Chl 
$a: C$ ratios for bay stations based either on the variables simulated by the ecosystem model or on measured data displayed the same pattern in 2002 and 2003 (Fig. 6).

When entered into the ecosystem model, the parameters estimated from P vs E curve measurements (i.e. "process simulation”, Table 2) along with the variable Chl $a$ :C ratio (Fig. 7b, d) gave phytoplankton dynamics close to those obtained with the reference simulations for both years (Fig. 7.a, c). However, the estimation of the determination coefficient for the process and the reference simulation indicated that the representation of standing stocks is better in the reference simulation $\left(r^{2}=0.55\right.$ for 2002 and $r^{2}=0.66$ for 2003) than in the process simulation ( $\mathrm{r}^{2}=0.49$ for 2002 and $\mathrm{r}^{2}=0.47$ for 2003).

In 2002, the process simulation enabled to simulate the autumn phytoplankton bloom with a slightly over-estimated magnitude, which was not shown by the reference simulation. The use of a fixed Chl $a$ :C ratio led to an over-estimation of the phytoplankton biomass in spring 2002 (Fig. 7b), whereas the best simulation was obtained using this fixed value in 2003 (Fig. 7d).

\section{Discussion}

Mechanistic or empirical relationships can be used to model ecological processes in an ecosystem. Mechanistic formulations are not commonly used in ecosystem modelling because all underlying mechanisms are not yet adequately documented. Empirical relationships are based on field and laboratory measurements. Baklouti et al. (2006b) argue that empirical formulations are more appropriate in data-rich areas than in under-sampled marine systems. The large data set available for the Baie des Veys estuary for 1.5 years enabled us to choose an empirical formulation rather than a complex mechanistic formulation to model phytoplankton processes. Data collection at fortnightly intervals (Jouenne et al., 2007) allowed adequate estimation of most of the process rates, as shown by Lawson et al. (1996). To our knowledge, no previous study provides a calibration for empirical formulations of primary production using a field data set of photosynthetic processes in natural phytoplankton assemblages. Jassby and Platt (1976) used a comparable data set in order to examine the behaviour of different formulations of the $\mathrm{P}$ vs $\mathrm{E}$ curves, but did not use it to calibrate rate processes. Struski and Bacher (2006) calibrated an empirical model of primary production based on biomass, photic depth and incident irradiance using field measurements of photosynthetic processes; however, the data set included only three sampling periods. Other 
studies were based only on monoalgal cultures in laboratory conditions (e.g. Geider et al., 1997 and references therein).

\subsection{Selection and calibration of the primary production model}

\subsubsection{Choice of the best formulation}

The first task was to choose the best empirical formulation of the photosynthesis vs irradiance response curve ( $\mathrm{P}$ vs E curve) for the Baie des Veys ecosystem. Five of the most frequently-used empirical formulations of the P vs E curves were compared in their ability to describe the available data set. The Webb et al. (1974), Jassby and Platt (1976), and Smith (1936) formulations described the observed P vs E curves reasonably well. Monod's (1950) and Steele's (1962) formulations did not adequately describe photosynthesis as a function of irradiance in this ecosystem. Furthermore, the Steele formulation indicated photoinhibition at high irradiance; however, measurements of primary productivity in the Baie des Veys never showed the existence of photoinhibition in this ecosystem (Jouenne et al., 2007). Steele's formulation is commonly used in ecosystem models to describe phytoplankton growth (Ebenhöh et al., 1997). Generally, results obtained with this formulation were consistent even if there was no photoinhibition in the ecosystem studied. Because of the strong influence of suspended particulate matter in coastal waters (Ebenhöh et al., 1997), irradiance seldom reaches levels at which photoinhibition occurs. Photoinhibition is a built-in feature of Steele's formulation, and the photosynthetic responses above and below the inhibition threshold are not independent (Jassby and Platt, 1976). In our study, Steele's equation over-estimated production for an intermediate irradiance. Because of this, we assume that in classical ecosystem models, the good fits obtained between measured and simulated biomass mainly resulted from parameter adjustment rather than adequate reproduction of rate processes (Brush et al., 2002). The aim of this work was to introduce a primary production model in an ecosystem model, thus, our final choice of Smith (1936) was motivated by the existence of an analytical solution for the depth-averaging effect, which avoids numerical integration (Duarte, 2006). Indeed, processing time is a major problem to consider in complex ecosystem models, particularly if the biogeochemical model is coupled with a two- or three-dimensional hydrodynamic model (Robson, 2005). However, the constant improvement of computational ability is gradually reducing this difficulty (Flynn, 2003b). 


\subsubsection{Parameter estimation and validation}

In empirical relationships, parameter estimation is not easy because parameter values depend mainly on the ecosystem under study and on the available data set. Thus, estimations vary widely in the literature (Sarthou et al., 2005). We decided to estimate parameters on rate processes (primary production) rather than standing stocks (chlorophyll $a$ ) in order to ensure that phytoplankton production was estimated as well as biomass (Zonneveld, 1998; Brush et al., 2002). In our opinion, this is an intermediate step between pure empirical formulations on biomass alone, and full mechanistic formulations as in Geider et al. (1996, 1998); however, our alternative solution can be used only for ecosystems where adequate photosynthetic process data are available. In this study parameter calibration was performed considering a reference temperature equal to $0^{\circ} \mathrm{C}$. To our knowledge, no data for $\mathrm{P}^{\mathrm{B}}$ ref and $\alpha^{\mathrm{B}}$ ref at $0^{\circ} \mathrm{C}$ exist in the literature. We extrapolated our results to $20^{\circ} \mathrm{C}$ in order to compare them with other published data as follows:

$\mathrm{P}_{\text {ref } 20^{\circ} \mathrm{C}}^{\mathrm{B}}=\mathrm{P}_{\text {ref } 0^{\circ} \mathrm{C}}^{\mathrm{B}} \exp \left(\mathrm{K}_{\mathrm{T}} \mathrm{T}\right)$ and $\alpha^{\mathrm{B}}{ }_{\text {ref } 20^{\circ} \mathrm{C}}=\alpha^{\mathrm{B}}{ }_{\text {ref } 0{ }^{\circ} \mathrm{C}} \exp \left(\mathrm{K}_{\mathrm{T}} \mathrm{T}\right)$

with $\mathrm{P}_{\text {ref } 0^{\circ} \mathrm{C}}^{\mathrm{B}}=0.84 \mathrm{mg} \mathrm{C} \mathrm{mg} \mathrm{Chl} a^{-1} \mathrm{~h}^{-1}, \alpha^{\mathrm{B}}{ }_{\text {ref } 0^{\circ} \mathrm{C}}=0.0091 \mathrm{mg} \mathrm{C} \mathrm{mg} \mathrm{Chl} a^{-1} \mathrm{~h}^{-1}\left(\mu \mathrm{E} \mathrm{m} \mathrm{m}^{-2}\right)^{-1}$, $\mathrm{K}_{\mathrm{T}}=0.12^{\circ} \mathrm{C}^{-1}$ and $\mathrm{T}=20^{\circ} \mathrm{C}$.

Results obtained for $\mathrm{P}^{\mathrm{B}}{ }_{\text {ref } 20^{\circ} \mathrm{C}}=9.26 \mathrm{mg} \mathrm{C} \mathrm{mg} \mathrm{Chl} a^{-1} \mathrm{~h}^{-1}$ and $\alpha^{\mathrm{B}}{ }_{\text {ref } 20^{\circ} \mathrm{C}}=0.1 \mathrm{mg} \mathrm{C} \mathrm{mg} \mathrm{Chl} a^{-1}$ $\mathrm{h}^{-1}\left(\mu \mathrm{E} \mathrm{m} \mathrm{m}^{-2} \mathrm{~s}^{-1}\right)^{-1}$ were similar to that reported by Lefebvre et al. (2007) for the diatom Skeletonema costatum. In a review of Geider et al. (1997 and references therein), values for diatom species ranged from 0.085 to $0.217 \mathrm{~h}^{-1}$ for the carbon-specific light-saturated photosynthesis rate and from 0.013 to $0.087 \mathrm{mg} \mathrm{C} \mathrm{mg} \mathrm{Chl} a^{-1} \mathrm{~h}^{-1}\left(\mu \mathrm{E} \mathrm{m} \mathrm{m}^{-2} \mathrm{~s}^{-1}\right)^{-1}$ for the Chl $a$ specific initial slope (values calculated from Geider et al. (1997)). These values are consistent with our results; $\mathrm{P}^{\mathrm{B}}$ ref varied between 0.092 and $0.278 \mathrm{~h}^{-1}$, depending on the value of the Chl $a: \mathrm{C}$ ratio used (Chl $a$ :C ranged from 0.01 to $0.03 \mathrm{mg} \mathrm{Chl} a \mathrm{mg} \mathrm{C}^{-1}$ ) and $\alpha^{\mathrm{B}}$ ref $=0.1 \mathrm{mg} \mathrm{C} \mathrm{mg}$ Chl $a^{-1} \mathrm{~h}^{-1}\left(\mu \mathrm{E} \mathrm{m} \mathrm{m}^{-2} \mathrm{~s}^{-1}\right)^{-1}$. In the literature, a positive correlation between $\mathrm{P}_{\max }^{\mathrm{B}}$ and $\alpha^{\mathrm{B}}$ commonly is observed (Behrenfeld et al., 2004) although this covariability has received little attention. Indeed, the Chl $a$-specific initial slope $\left(\alpha^{\mathrm{B}}\right)$ usually is considered to be a constant. Several authors (Keller, 1989; Sakshaug et al., 1989; Geider et al., 1997) suggest that $\alpha^{\mathrm{B}}$ can vary with changes in environmental variables. The similarity obtained between the temporal variations of $\mathrm{P}^{\mathrm{B}}$ max and $\alpha^{\mathrm{B}}$ (Figs. 5 a and b) led us to introduce a variable $\alpha^{\mathrm{B}}$ depending on nutrient availability and temperature. The formulation of $\alpha^{\mathrm{B}}$ uses the same equation and parameters as does $\mathrm{P}^{\mathrm{B}}{ }_{\max }$ (Eqs. 6 and 7, Table 2). According to Geider et al. (1997) environmental conditions can influence the initial slope within a species. But they also 
suggest that the initial slope vary more amongst species. We modelled a community, thus, we assumed that the simulation of the variations of the initial slope depending on environmental conditions enabled to take into account change in the community structure along with change within species. In contrast, in more classical approach where a fixed optimal light intensity is used to model communities like diatoms or flagellates, changes in community structure are not taken into account.

Parameter values for the half-saturation constants for nutrient uptake (nitrogen and silicate) are consistent with values available in the literature. This is not surprising due to the wide range of values published (Keller, 1989). In a review, Sarthou et al. (2005) indicated that the half-saturation constant for nitrogen $\left(\mathrm{K}_{\mathrm{N}}\right)$ varies between 0.02 and $10.2 \mu \mathrm{M}$, with an average of $1.6 \pm 1.9 \mu \mathrm{M}$, and the half-saturation constant for silicate $\left(\mathrm{K}_{\mathrm{Si}}\right)$ varies between 0.2 and 22 $\mu \mathrm{M}$, with an average of $3.9 \pm 5 \mu \mathrm{M}$. In ecosystem models, the range of parameter values used is narrower. Generally, $K_{N}$ ranges from 0.1 to $2 \mu \mathrm{M}$ and $K_{S i}$ from 0.3 to $2.5 \mu \mathrm{M}$ (e.g. Keller, 1989; Fasham et al., 1990; Baretta-Bekker et al., 1994; Ménesguen and Hoch, 1997). This indicates a high sensitivity of the models to these parameters. These results highlight the importance of accurately estimating parameters for a given ecosystem.

One limitation of our work comes from the empirical formulation of processes, because the model should perform well only if the empirical model behaviour does not deviate far from the calibration data set (Baird et al., 2003). In order to avoid dependency between model and measurements, it is only possible to use a mechanistic approach like quota models, because parameters then are constrained by theoretical interpretations of processes, not by the data set. The use of quota models has the advantage of linking growth with the internal availability of nutrients by integrating intracellular storage pools (Droop, 1973, 1974). This approach allows separation of uptake from growth. Nutrient uptake depends hyperbolically on the nutrient concentration external to the cell (Zonneveld, 1996) using Monod uptake kinetics (Monod, 1950), whereas growth depends only on the intracellular quotas of nutrients (Droop, 1973). The concept of quota models is considered more realistic because if there are no more nutrients in the environment, growth can continue with nutrients previously accumulated in the cells (Collins, 1980; Haney and Jackson, 1996). This can explain the discrepancies between the maximum measured and simulated photosynthetic rates in summer. The simulation of $\mathrm{P}^{\mathrm{B}}$ max without nutrient limitation (Fig. 5a) showed an adequate fit in late summer 2002. This indicated that the production in summer mainly was influenced by temperature, not by nutrient availability. Some nutrient inputs from river pulses or from sediment remineralization can provide sufficient nutrients to sustain phytoplankton 
production. This assumption agrees with Jouenne et al. (2007), who observed that in summer 2002 and 2003, the Baie des Veys ecosystem was dominated by large diatoms with high biovolumes (> $150000 \mu^{3}$ cell $^{-1}$ ), which were favoured by their capacity to store nutrients (Pannard et al., 2007). In contrast, the simulation of $\mathrm{P}^{\mathrm{B}}{ }_{\max }$ without nutrient limitation in 2003 over-estimated production, which indicated low nutrient availability. Because at that time communities also were dominated by large cells, we assume that use of a quota model would improve simulation of production in late summer 2002 and 2003 by considering nutrients stored in the cells. However, if species diversity is the major source of variability, the many species-specific parameters make it difficult to use such complex quota models for mixedspecies populations in natural water bodies (Keller, 1989; Baird et al., 2001).

\subsection{Application of processes in the ecosystem model of the Baie des Veys estuary}

Use of measured photosynthetic processes in an ecosystem model requires a conversion factor between phytoplankton productivity and growth rate; the cellular ratio of chlorophyll $a$ to carbon (Chl $a$ :C). The variability of the $\mathrm{Chl} a$ :C ratio, which indicates the algal photoacclimative status (Geider et al., 1998), is related to irradiance, nutrient availability, and temperature (e.g. Geider, 1987; Cloern et al., 1995; Geider et al., 1998).

First, we opted for simplicity using a fixed Chl $a$ :C ratio $\left(0.03 \mathrm{mg} \mathrm{Chl} a \mathrm{mg} \mathrm{C}^{-1}\right)$. Those results inadequately simulated phytoplankton dynamics in 2002 (Fig. 7b); however in 2003, the best simulation of the spring bloom was obtained with this constant ratio (Fig. 7d). The Chl $a$ :C ratio in the Baie des Veys ecosystem estimated from the formulation developed by Cloern et al. (1995) showed seasonal variability for the two years studied (Fig. 6). Thus, it is surprising that the best fit was obtained using a fixed value in 2003 (Fig. 7d). The comparison between the estimated $\mathrm{Chl} a$ :C ratios based either on the variables simulated by the ecosystem model or on measured data displayed the same pattern. This indicates an adequate implementation of the $\mathrm{Chl} a$ :C ratio into the ecosystem model: the year 2003 was a dry one characterized by low river inputs and higher water temperature (Jouenne et al., 2007). These exceptional environmental conditions led to a shift in the development of the phytoplankton spring bloom which occurred one month sooner in 2003 (April) than in 2002 (May), a more normal year (Fig. 7). For the two years studied the use of a fixed Chl $a$ :C ratio led to a development of the spring bloom around April. The observed shift in phytoplankton dynamics can explain why in 2003 the best simulation was obtained with the fixed value of the Chl $a: \mathrm{C}$ ratio. These results also indicates that the formulation of the Chl $a: \mathrm{C}$ ratio 
developed by Cloern et al. (1995) did not explain all the variability in the data. This formulation was established using published studies performed on cultures grown in the laboratory at steady-state under controlled conditions of light, temperature and nutrient. The correlation obtained by Cloern et al. (1995) between calculated and measured Chl $a$ :C ratio showed that $60 \%$ of the variance contained in the data sets was explained by this relation. Although Cloern's empirical formulation take into account a certain diversity of size (14 monoalgal cultures), these differences can partly explain why all the variability in the chlorophyll $a$ dynamics was not adequately reproduce using a variable $\mathrm{Chl} a$ : $\mathrm{C}$ ratio in a community of mixed-species populations. From our point of view, the implementation of the empirical relationship of the Chl $a$ :C ratio developed by Cloern et al. (1995) is relevant in a biogeochemical model based on empirical formulation of rate processes. Finkel (2001) showed that the Chl $a$ :C ratio is highly correlated with cell size in marine diatoms. This feature is not explicitly included in the empirical formulation of Cloern et al. (1995). An interesting improvement will be to take into account the cell size dependence on the Chl $a: \mathrm{C}$ ratio, however, we thought that before making more complex the formulation of the Chl $a: \mathrm{C}$ ratio it will be more pertinent to develop size-resolved ecosystem models rather than biomass ecosystem models (Baird and Suthers, 2007).

The process simulation using parameters estimated from primary production measurements display similar patterns than the reference simulation for chlorophyll $a$ standing stocks (Fig. 7). Furthermore, the use of our method led directly to a satisfactory representation of the Baie des Veys phytoplankton dynamics without additional calibration of parameters. However, the metric of model assessment (i.e. see determination coefficients $\S$ 3.2.) indicated that the representation of standing stocks is better in the reference simulation than in the process simulation. In the reference simulation we used the same parameters than those from Guillaud et al. (2000). The maximum growth rate and the optimal light intensity usually were calibrated in modelling studies. In contrast, the half-saturation constants for nitrogen and silicates uptake came from cultured experiments performed in controlled conditions for several marine phytoplankton species. The use of these parameters led to an adequate simulation of chlorophyll $a$ and nutrients standing stocks (i.e. "reference simulation”). However, these parameters were adjusted from other ecosystems or estimated in laboratory experiments, thus it is not possible to ensure that underlying mechanisms are adequately simulated. Indeed, due to the high range of published parameter values (Sarthou et al., 2005) we assumed that the use of another parameter set could lead to the same representation of chlorophyll $a$ standing stocks. Generally, in most modelling studies 
validation was performed by estimating the difference between measured and simulated standing stocks. In this approach, productivity rates were not explicitly taken into account. Thus, it is not possible to determine if the good fit obtained is the result of an adequate representation of processes or only a consequence of parameter adjustment (Brush et al., 2002). Because in ecosystems all compartments are closely linked, an adequate representation of chlorophyll $a$ standing stocks could be just as well the result of a misrepresenting of primary production compensated by a misrepresenting of other processes (e.g. mortality rates, grazing by zooplankton, etc.) as the result of an adequate representation of primary production. In the process simulation, phytoplankton rate processes were estimated directly on field primary production measurements: thus, we can consider that primary production processes are adequately simulated by the ecosystem model. Estimation of annual primary production through the ecosystem model gave a rate of $139 \mathrm{~g} \mathrm{C} \mathrm{m}^{-2} \mathrm{y}^{-1}$ in the process simulation versus $110 \mathrm{~g} \mathrm{C} \mathrm{m}^{-2} \mathrm{y}^{-1}$ in the reference simulation for 2002, and a rate of $104 \mathrm{~g} \mathrm{C}$ $\mathrm{m}^{-2} \mathrm{y}^{-1}$ in the process simulation versus $92 \mathrm{~g} \mathrm{C} \mathrm{m}^{-2} \mathrm{y}^{-1}$ in the reference simulation for 2003 . Calibration of parameters on rate processes lead to increases of the estimated annual primary production of $13 \%$ and $26 \%$ compared with those obtained in the reference simulation. This indicates that parameters used in the reference simulation induce an under-estimation of the Baie des Veys annual primary production. Thus, because the simulations of chlorophyll $a$ standing stock were almost similar in the two approaches, our results highlighted some differences in the underlying photosynthetic processes. This point is critically important because an adequate representation of standing stock without validation of productivity rate may imply a misrepresentation of other features of the ecosystem in compensation (Flynn, 2005).

\section{Conclusion}

This study was undertaken to improve the representation of phytoplankton rate processes in ecosystem models using field measurements of primary production. We provided an approach based on empirical relationships to calibrate and assess primary production processes in an ecosystem model without using complex mechanistic formulations. The introduction of parameters estimated from productivity data in an ecosystem box model led directly to an adequate simulation of phytoplankton dynamics. Furthermore, estimations of the annual primary production were $13 \%$ and $26 \%$ higher in our approach compared with the reference simulation. Nevertheless, some under-estimation of production remained in late 
summer for the two years studied. In our opinion, this discrepancy was explained by the formulation of nutrient limitation, which did not account for the existence of intracellular nutrient storage pools. An improvement would be use of a more mechanistic approach like quota models in order to consider the effect of nutrients on assimilation and growth. However, the introduction of quota models in ecosystem models is not easy, especially for ecosystems with numerous micro-algal successions. In order to account for populations or communities structure, it will be necessary to develop more complex ecosystem models like size-resolved models (e.g. Baird and Suthers, 2007), or population models (e.g. Baird and Emsley, 1999) rather than biomass models. Similarly, the use of a variable Chl $a: C$ ratio is essential to adequately reproduce the seasonal pattern of phytoplankton dynamics; nevertheless, in numerous ecosystem models, only a simple conversion factor is used. The formulation in our study was empirical because it was based on phytoplankton grown under steady-state conditions in the laboratory. Future dynamic ecosystem models will become more realistic when using a mechanistic approach that describes the underlying mechanisms of photoacclimation, such as those developed by Geider et al. (1998). In our opinion, our approach has the main advantages of being less difficult to undertake than the implementation of complex mechanistic formulations into ecosystem models. However, our results were strongly dependent on the large available data set of P vs E curves. Although similar data set are not usually available in all ecosystems, we thought that the constant increase of monitoring network could lead to more measurements of primary production. Thus, in ecosystems with a similar data set, our approach could be used to improve calibration of processes in dynamic simulation models. In other cases, we believe that the use of mechanistic formulations of processes in ecosystem models is essential in order to adequately represent rate processes as well as standing stocks.

\section{Acknowledgements}

This work was supported by IFREMER and by the Conseil Régional de Basse-Normandie (France). The authors would like to gratefully acknowledge Cédric Bacher and Pascal Claquin for constructive comments. We also would like to thank Jennifer Purcell at Sea Pen Scientific Writing LLC for editorial assistance. We appreciate the insightful comments and suggestions of two anonymous reviewers. 


\section{References}

Baird, M.E., Emsley, S.M., 1999. Towards a mechanistic model of plankton population dynamics. Journal of Plankton Research 21, 85-126.

Baird, M.E., Emsley, S.M., McGlade, J.M., 2001. Modelling the interacting effects of nutrient uptake, light capture and temperature on phytoplankton growth. Journal of Plankton Research 23, 829-840.

Baird, M.E., Walker, S.J., Wallace, B.B., Webster, I.T., Parslow, J.S., 2003. The use of mechanistic descriptions of algal growth and zooplankton grazing in an estuarine eutrophication model. Estuarine Coastal and Shelf Science 56, 685-695.

Baird, M.E., Suthers, I.M., 2007. A size-resolved pelagic ecosystem model. Ecological Modelling 203, 185-203.

Baklouti, M., Faure, V., Pawlowski, L., Sciandra, A., 2006a. Investigation and sensitivity analysis of a mechanistic phytoplankton model implemented in a new modular numerical tool (Eco3M) dedicated to biogeochemical modelling. Progress in Oceanography 71, 34-58.

Baklouti, M., Diaz, F., Pinazo, C., Faure, V., Queguiner, B., 2006b. Investigation of mechanistic formulations depicting phytoplankton dynamics for models of marine pelagic ecosystems and description of a new model. Progress in Oceanography 71, 133.

Baretta, J.W., Ruardij, P., Vested, H.J., Baretta-Bekker, J.G., 1994. Eutrophication modelling of the North Sea: two different approaches. Ecological Modelling 75-76, 471-483.

Baretta-Bekker, J.G., Riemann, B., Baretta, J.W., Koch Rasmussen, E., 1994. Testing the microbial loop concept by comparing mesocosm data with results from a dynamical simulation model. Marine Ecology Progress Series 106, 187-198.

Behrenfeld, M.J., Prasil, O., Babin, M., Bruyant, F., 2004. In search of a physiological basis for covariations in light-limited and light-saturated photosynthesis. Journal of Phycology 40, 4-25.

Brush, M.J., Brawley, J.W., Nixon, S.W., Kremer, J.N., 2002. Modeling phytoplankton production: problems with the Eppley curve and an empirical alternative. Marine Ecology Progress Series 238, 31-45.

Cloern, J.E., Grenz, C., Vidergar-Lucas, L., 1995. An empirical model of the phytoplankton chlorophyll: carbon ratio-the conversion factor between productivity and growth rate. Limnology and Oceanography 40, 1313-1321. 
Collins, C.D., 1980. Formulation and validation of a mathematical model of phytoplankton growth. Ecology 61, 639-649.

Cugier, P., Ménesguen, A., Guillaud, J.F., 2005. Three-dimensional (3D) ecological modelling of the Bay of Seine (English Channel, France). Journal of Sea Research 54, 104-124.

Desprez, M., Ducrotoy, J.-P., Sylvand, B., 1986. Fluctuations naturelles et évolution artificielle des biocénoses macrozoobenthiques intertidales de trois estuaires des côtes françaises de la Manche. Hydrobiologia 142, 249-270.

Droop, M.R., 1973. Some thoughts on nutrient limitation in algae. Journal of Phycology 9, 264-272.

Droop, M.R., 1974. The nutrient status of algal cells in continuous culture. Journal of the Marine Biological Association of the United Kingdom 54, 825-855.

Duarte, P., 2006. Photosynthesis-Irradiance relationships in marine microalgae. In: D.V. Subba Rao (Editor), Algal Cultures Analogues of Blooms and Applications. Science Publishers, Enfield, NH, pp. 639-683.

Dubois, S., Marin-Leal, J.C., Ropert, M., Lefebvre, S., 2007. Effects of oyster farming on macrofaunal assemblages associated with Lanice conchilega tubeworm populations: a trophic analysis using natural stable isotopes. Aquaculture 271, 336-349.

Ebenhöh, W., Baretta-Bekker, J.G., Baretta, J.W., 1997. The primary production module in the marine ecosystem model ERSEM II, with emphasis on the light forcing. Journal of Sea Research 38, 173-193.

Eppley, R.W., 1972. Temperature and phytoplankton growth in the sea. Fishery Bulletin 70, 1063-1085.

Fasham, M.J.R., Ducklow, H.W., McKelvie, S.M., 1990. A nitrogen-based model of plankton dynamics in the oceanic mixed layer. Journal of Marine Research 48, 591-639.

Finkel, Z.V., 2001. Light absorption and size scaling of light-limited metabolism in marine diatoms. Limnology and Oceanography 46, 86-94.

Flynn, K.J., 2003a. Do we need complex mechanistic photoacclimation models for phytoplankton? Limnology and Oceanography 48, 2243-2249.

Flynn, K.J., 2003b. Modelling multi-nutrient interactions in phytoplankton; balancing simplicity and realism. Progress in Oceanography 56, 249-279.

Flynn, K.J., 2005. Modelling marine phytoplankton growth under eutrophic conditions. Journal of Sea Research 54, 92-103. 
Geider, R.J., 1987. Light and temperature dependence of the carbon to chlorophyll $a$ ratio in microalgae and cyanobacteria: implications for physiology and growth of phytoplankton. New Phytologist 106, 1-34.

Geider, R.J., MacIntyre, H.L., Kana, T.M., 1996. A dynamic model of photoadaptation in phytoplankton. Limnology and Oceanography 41, 1-15.

Geider, R.J., MacIntyre, H.L., Kana, T.M., 1997. Dynamic model of phytoplankton growth and acclimation: responses of the balanced growth rate and the chlorophyll $a$ : carbon ratio to light, nutrient-limitation and temperature. Marine Ecology Progress Series $148,187-200$.

Geider, R.J., MacIntyre, H.L., Kana, T.M., 1998. A dynamic regulatory model of phytoplanktonic acclimation to light, nutrients, and temperature. Limnology and Oceanography 43, 679-694.

Guillaud, J.F., Andrieux, F., Ménesguen, A., 2000. Biogeochemical modelling in the Bay of Seine (France): an improvement by introducing phosphorus in nutrient cycles. Journal of Marine Systems 25, 369-386.

Haney, J.A., Jackson, G.A., 1996. Modeling phytoplankton growth rates. Journal of Plankton Research 18, 63-85.

Jassby, A.D., Platt, T., 1976. Mathematical formulation of the relationship between photosynthesis and light for phytoplankton. Limnology and Oceanography 21, 540541.

Jouenne, F., Lefebvre, S., Veron, B., Lagadeuc, Y., 2007. Phytoplankton community structure and primary production in small intertidal estuarine-bay ecosystem (eastern English Channel, France). Marine Biology 151, 805-825.

Keller, A.A., 1989. Modeling the effects of temperature, light, and nutrients on primary productivity: an empirical and a mechanistic approach compared. Limnology and Oceanography 34, 82-95.

Lawson, L.M., Hofmann, E.E., Spitz, Y.H., 1996. Time series sampling and data assimilation in a simple marine ecosystem model. Deep Sea Research (Part II, Topical Studies in Oceanography) 43, 625-651.

Lefebvre, S., Mouget, J.L., Loret, P., Rosa, P., Tremblin, G., 2007. Comparison between fluorimetry and oximetry techniques to measure photosynthesis in the diatom Skeletonema costatum cultivated under simulated seasonal conditions. Journal of Photochemistry and Photobiology B: Biology 86, 131-139. 
Ménesguen, A., Hoch, T., 1997. Modelling the biogeochemical cycles of elements limiting primary production in the English Channel. 1. Role of thermohaline stratification. Marine Ecology Progress Series 146, 173-188.

Ménesguen, A., Cugier, P., Loyer, S., Vanhoutte-Brunier, A., Hoch, T., Guillaud, J.-F., Gohin, F., 2007. Two- or three-layered box-models versus fine 3D models for coastal ecological modelling? A comparative study in the English Channel (Western Europe). Journal of Marine Systems 64, 47-65.

Mesplé, F., Trousselier, M., Casellas, C., Legendre, P., 1996. Evaluation of simple statistical criteria to qualify a simulation. Ecological Modelling 88, 9-18.

Monod, J., 1949. The growth of bacterial cultures. Annual Review of Microbiology 3, 371394.

Monod, J., 1950. La technique de culture continue. théorie et applications. Annales de l'Institut Pasteur 79, 390-410.

Nelder, J.A., Mead, R., 1965. A simplex method for function minimization. The Computer Journal 7, 308-313.

Pannard, A., Bormans, M., Lefebvre, S., Claquin, P., Lagadeuc, Y., 2007. Phytoplankton size distribution and community structure: influence of nutrient input and sedimentary loss. Journal of Plankton Research 29, 583-598.

Platt, T., Denman, K.L., Jassby, A.D., 1975. The mathematical representation and prediction of phytoplankton productivity, Fisheries Marine Service Technical Report, pp. 110.

Robson, B.J., 2005. Representing the effects of diurnal variations in light on primary production on a seasonal time-scale. Ecological Modelling 186, 358-365.

Sakshaug, E., Andresen, K., Kiefer, D.A., 1989. A steady state description of growth and light absorption in the marine planktonic diatom Skeletonema costatum. Limnology and Oceanography 34, 198-205.

Sakshaug, E., Bricaud, A., Dandonneau, Y., Falkowski, P.G., Kiefer, D.A., Legendre, L., Morel, A., Parslow, J., Takahashi, M., 1997. Parameters of photosynthesis: definitions, theory and interpretation of results. Journal of Plankton Research 19, 1637-1670.

Sarthou, G., Timmermans, K.R., Blain, S., Tréguer, P., 2005. Growth physiology and fate of diatoms in the ocean: a review. Journal of Sea Research 53, 25-42.

Smith, E.L., 1936. Photosynthesis in relation to light and carbon dioxide. Proceedings of the National Academy of Sciences 22, 504-511. 
Steele, J.H., 1962. Environmental control of photosynthesis in the sea. Limnology and Oceanography 7, 137-150.

Strickland, J.D.H., 1960. Measuring the production of marine phytoplankton. Bulletin of the Fisheries Research Board of Canada 122, 1-172.

Struski, C., Bacher, C., 2006. Preliminary estimate of primary production by phytoplankton in Marennes-Oléron Bay, France. Estuarine Coastal and Shelf Science 66, 323-334.

Webb, W.L., Newton, M., Starr, D., 1974. Carbon dioxide exchange of Alnus rubra: a mathematical model. Oecologia 17, 281-291.

Zonneveld, C., 1996. Modelling the kinetics of non-limiting nutrients in microalgae. Journal of Marine Systems 9, 121-136.

Zonneveld, C., 1998. Light-limited microalgal growth: a comparison of modelling approaches. Ecological Modelling 113, 41-54. 


\section{Figure captions}

Fig 1: Map of the study area, the Baie des Veys estuary (modified after Dubois et al., 2007). The black box corresponds to the geographical area used in the box model of the Baie des Veys. The five points represent the sampling stations. Four are located in the bay and one in the estuary.

Fig 2: Conceptual diagram of the biogeochemical model for the Baie des Veys ecosystem.

Fig 3: Fits of the five studied equations for one example of photosynthesis versus irradiance (P vs. E) response curve measured on April 14, 2003 in the Baie des Veys ecosystem. At this sampling date, available P vs E curves were averaged spatially and vertically for the four bay stations (average values and standard deviations were indicated).

Fig 4: Relationship between primary production measured in the Baie des Veys estuary and simulated from the Smith (1936) equation. The solid line represents the linear regression between both variables ( $\mathrm{n}=1335)$.

Fig 5: Variation of (a) the maximum photosynthetic rate $\left(\mathrm{P}_{\max }^{\mathrm{B}}\right)$ and (b) the maximum light utilization coefficient $\left(\alpha^{\mathrm{B}}\right)$ in the Baie des Veys between May 2002 and October 2003. Solid lines represent data. Dashed lines represent simulations with temperature and nutrient limitations. Dotted lines represent simulations with temperature limitation but without nutrient limitation. At each sampling time, data were averaged spatially and vertically for the four bay stations (average values and standard deviations were indicated).

Fig 6: Variation of Chl a:C ratio calculated from data measured in the Baie des Veys (solid line) and in the estuary (dashed line) for May 2002 through October 2003 using the formulation developed by Cloern et al. (1995). At each time, data were averaged spatially and vertically for the four bay stations and vertically for the estuary station (average values and standard deviations were indicated). Simulation of the time course of the Chl $a$ :C ratio in 2002 and 2003 (dotted line) within the ecosystem model using the Cloern formulation implemented into the ecosystem model. 
Fig 7: Simulation of the time course of the Baie des Veys chlorophyll $a$ concentrations in 2002 (a) and (b) and 2003 (c) and (d). In the reference simulations (a) and (c) the model was fit using published parameter values so that simulated chlorophyll $a$ was closest to measured chlorophyll $a$. In the process simulations (b) and (d), models were fit using parameters estimated from rate processes. Dashed lines correspond to a variable $\mathrm{Chl} a$ :C ratio and solid lines correspond to a fixed $\mathrm{Chl} a$ :C ratio of $0.03 \mathrm{mg} \mathrm{Chl} a \mathrm{mg} \mathrm{C}^{-1}$. Dot corresponds to chlorophyll $a$ measurements performed at the north station. 
Figure 1

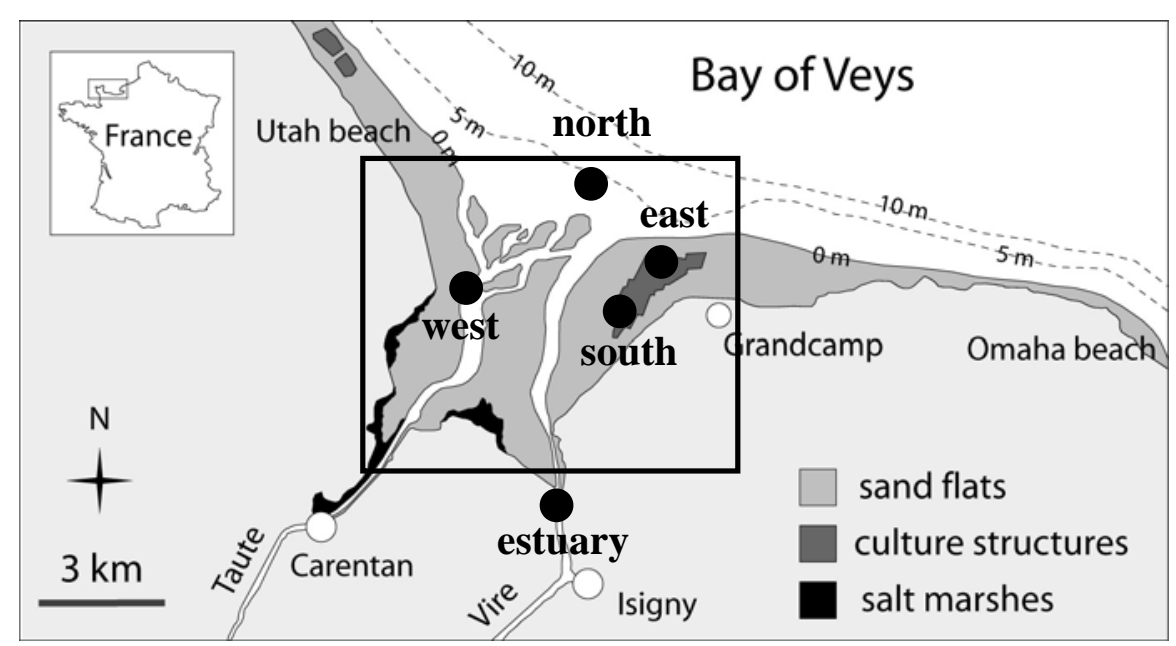


Figure 2

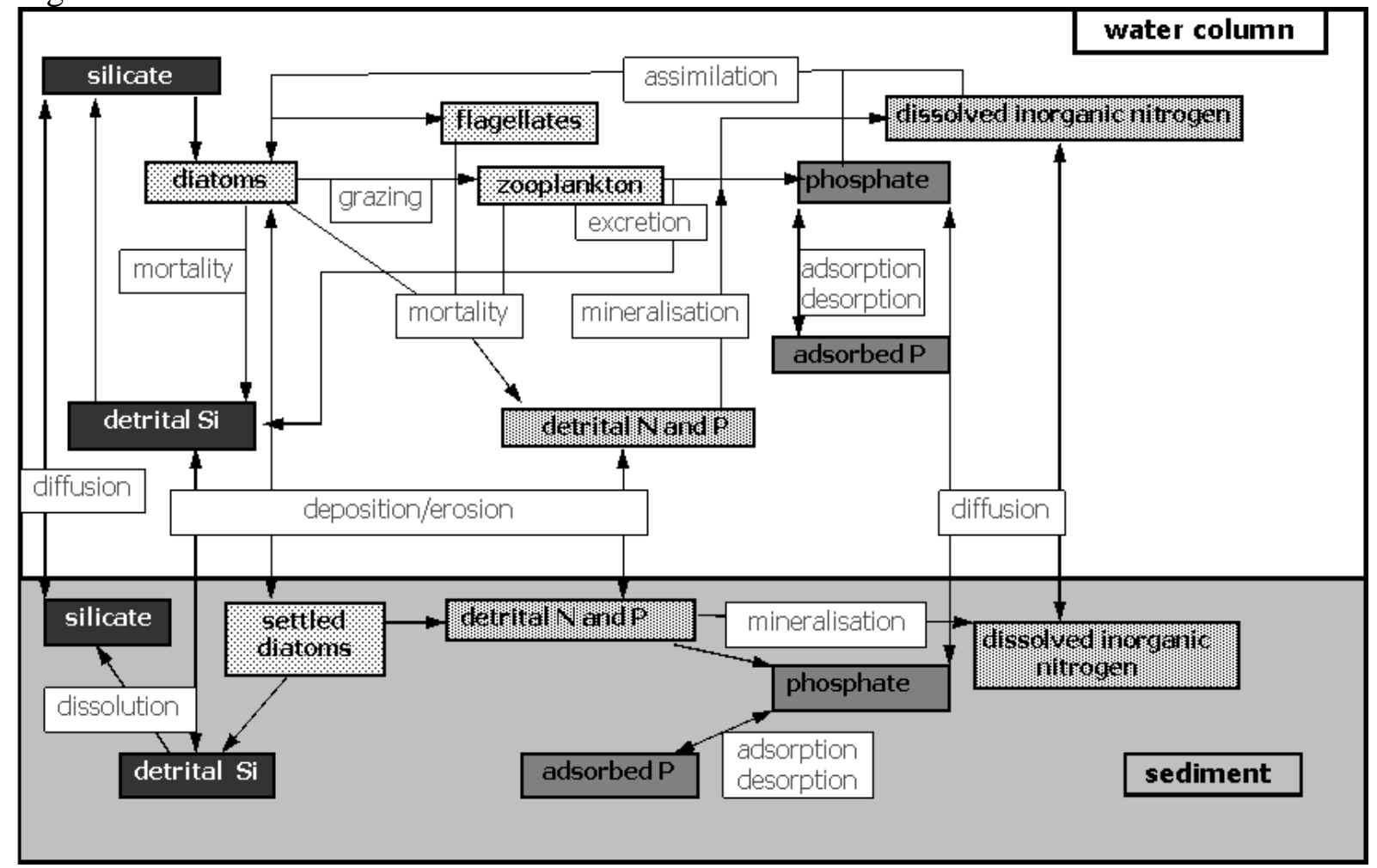


Figure 3

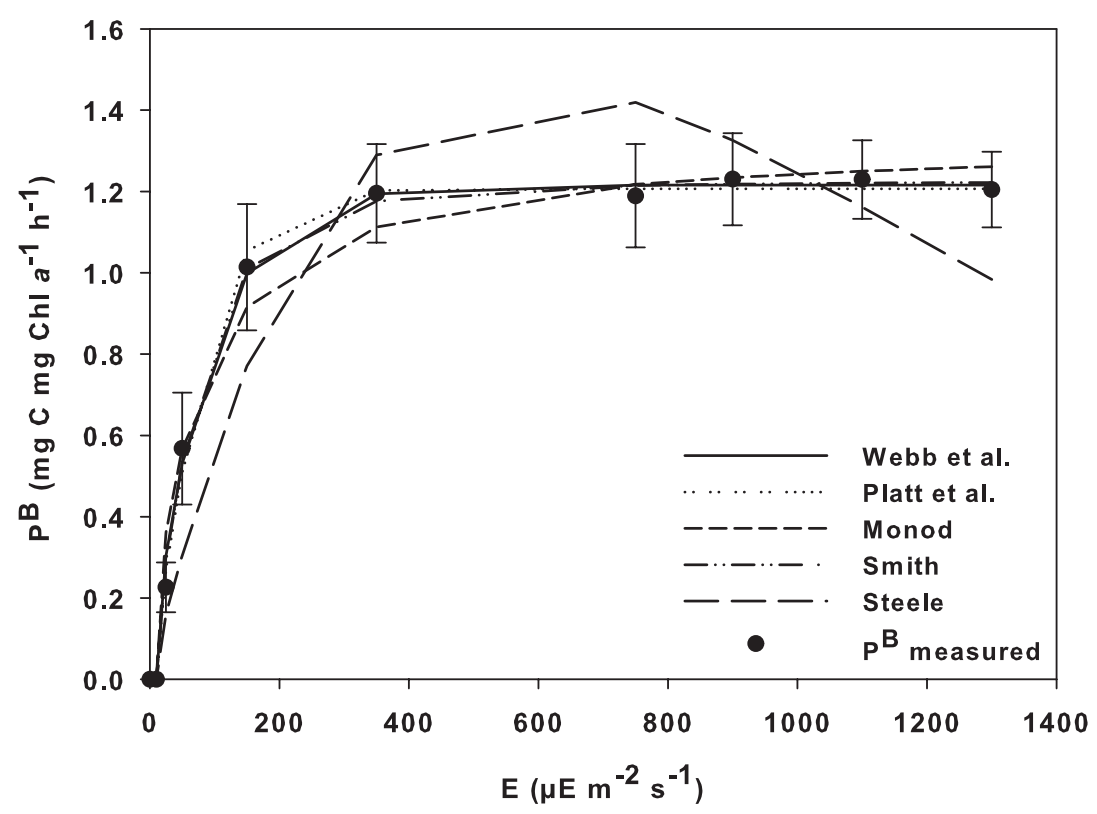


Figure 4

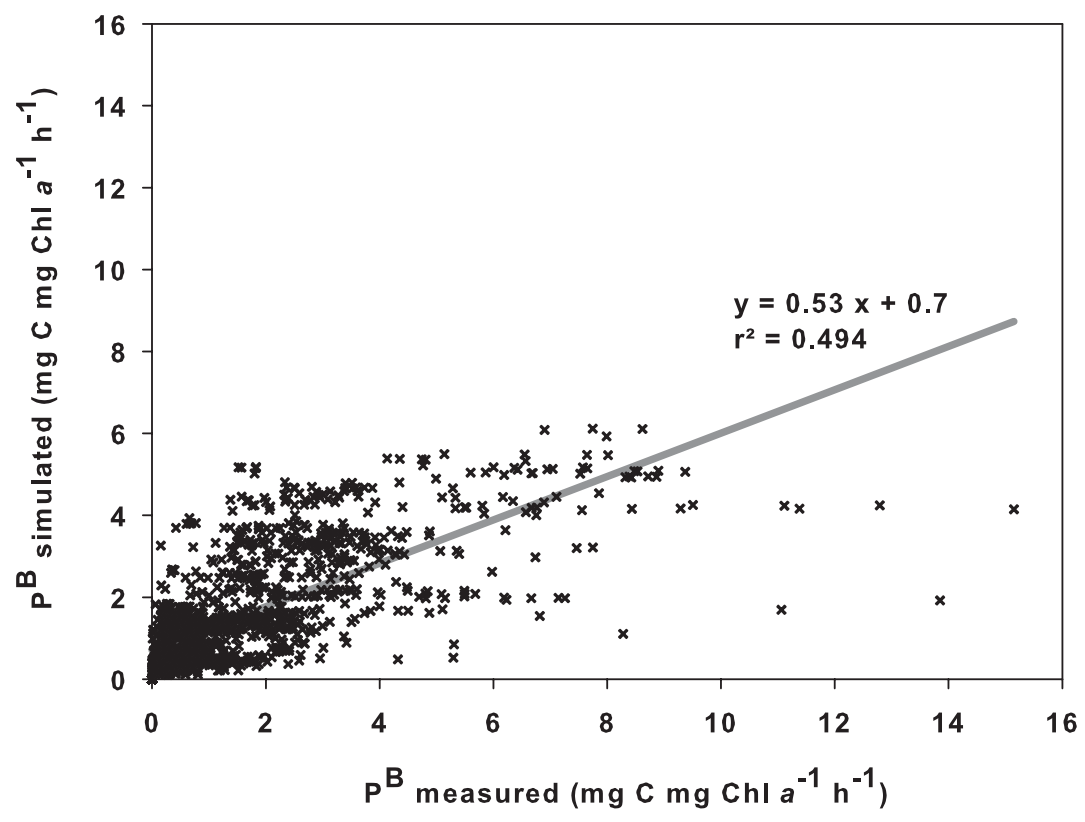


Figure 5

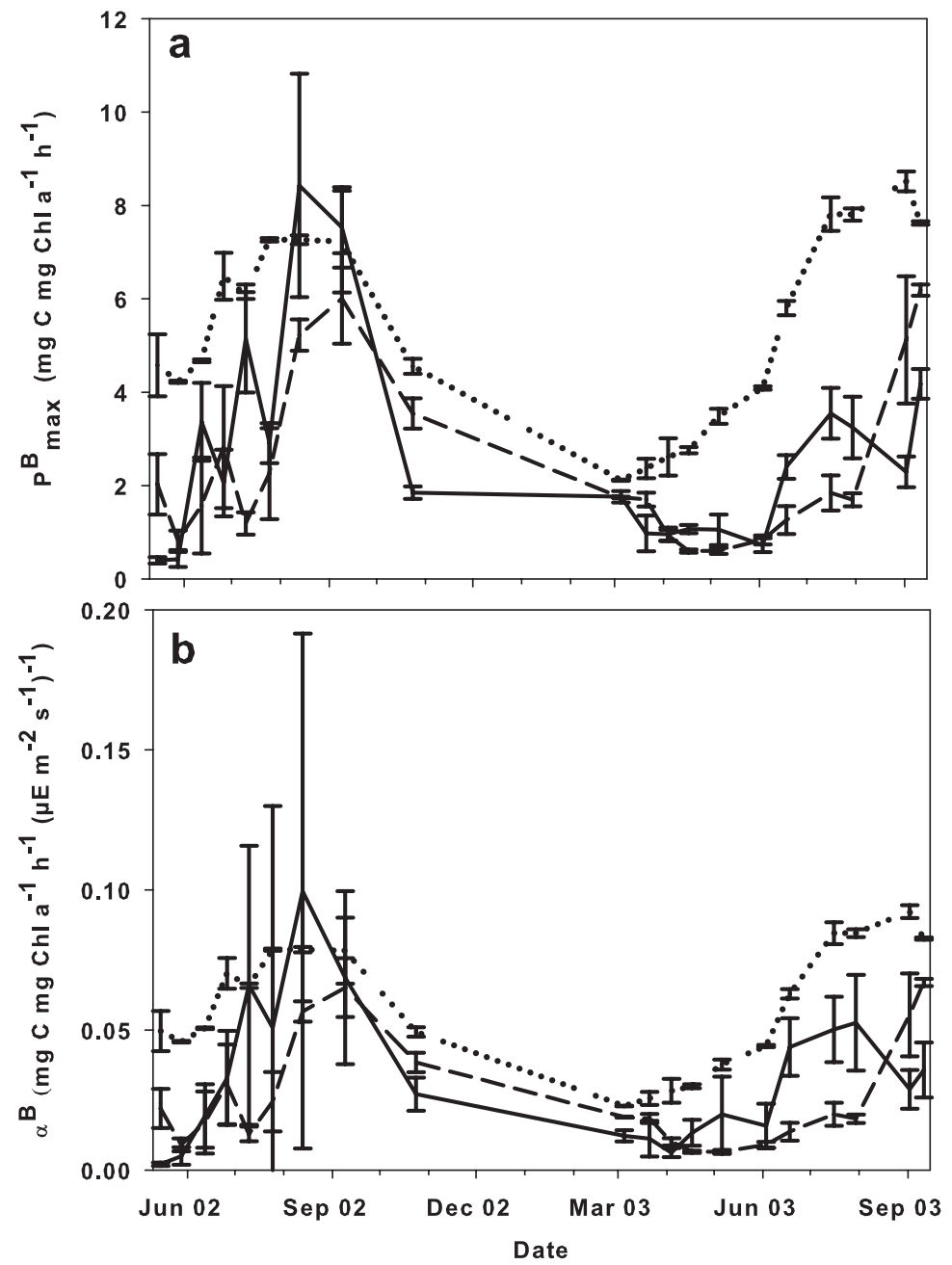


Figure 6

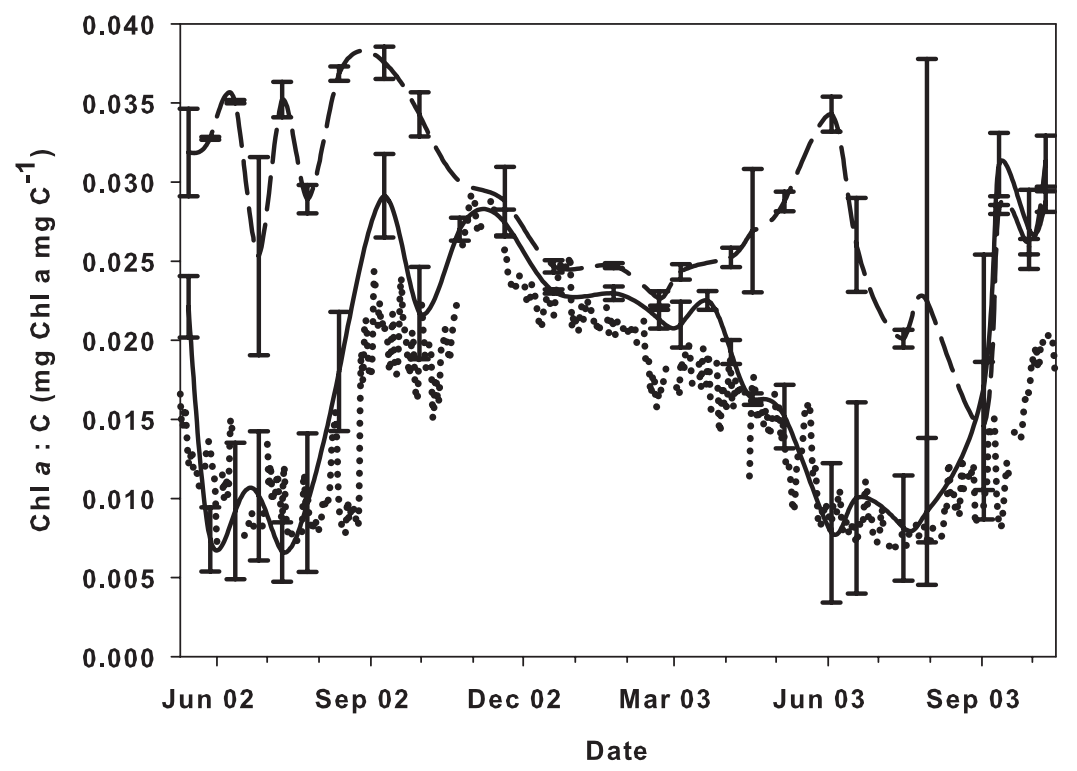


Figure 7

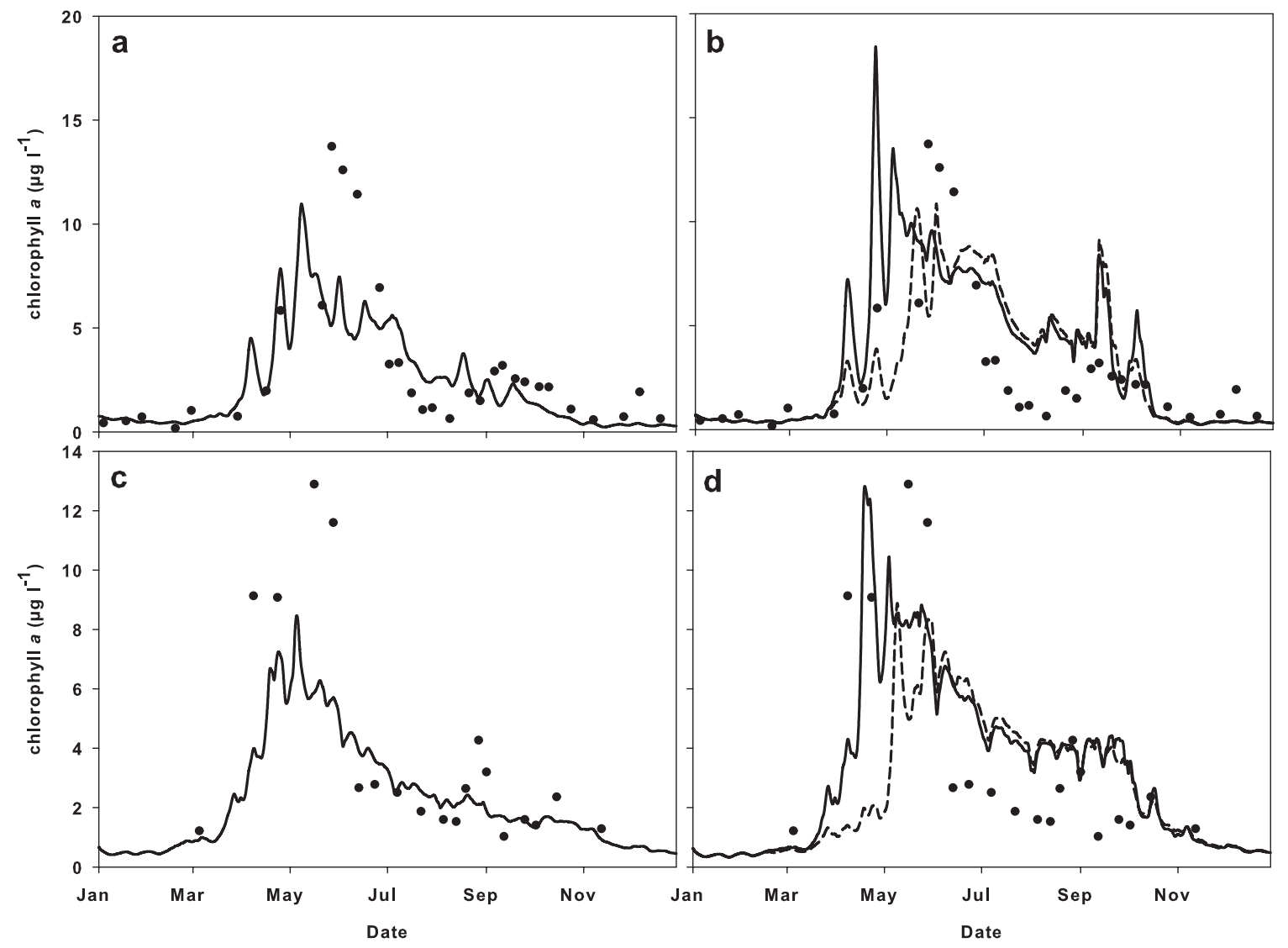


Table 1: Mathematical formulations of the photosynthesis rate limitation. All equations have been expressed in terms of the photosynthetic parameters $\mathrm{P}_{\text {max }}^{\mathrm{B}}$, which is the maximum photosynthetic rate (in mg C mg Chl $a^{-1} \mathrm{~h}^{-1}$ ) and $\alpha^{\mathrm{B}}$, which is the maximum light utilization coefficient in (mg C mg Chl $a^{-1} \mathrm{~h}^{-1}\left(\mu \mathrm{E} \mathrm{m}^{-2} \mathrm{~s}^{-1}\right)^{-1}$ ). $\mathrm{P}^{\mathrm{B}}$ (in mg C mg Chl $a^{-1} \mathrm{~h}^{-1}$ ) is the primary production rate standardized to chlorophyll $a$ biomass B (mg Chl $a$ ). E is the incident light intensity available for phytoplankton $\left(\mu \mathrm{E} \mathrm{m} \mathrm{m}^{-2}\right)$. The determination coefficient corresponds to an estimation of the goodness-of-fit between measured and simulated primary production.

\begin{tabular}{|c|c|c|c|}
\hline Index & Equation & Reference & $\mathrm{R}^{2}$ \\
\hline (1) & $P^{B}=P_{\max }^{B}\left[1-\exp \left(\frac{-\alpha^{B} E}{P_{\max }^{B}}\right)\right]$ & Webb et al. (1974) & 0.500 \\
\hline (2) & $P^{B}=P_{\max }^{B} \tanh \left(\frac{\alpha^{B} E}{P_{\max }^{B}}\right)$ & Platt et al. (1975) & 0.497 \\
\hline (3) & $P^{B}=P_{\max }^{B} \frac{\alpha^{B} E}{\left(P_{\max }^{B}+\alpha^{B} E\right)}$ & Monod (1950) & 0.487 \\
\hline (4) & $P^{B}=P_{\max }^{B}\left[\frac{\alpha^{B} E}{\sqrt{\left(P_{\max }^{B}\right)^{2}+\left(\alpha^{B} E\right)^{2}}}\right]$ & Smith (1936) & 0.494 \\
\hline (5) & $P^{B}=\alpha^{B} E \exp \left(1-\frac{\alpha^{B} E}{P_{\max }^{B}}\right)$ & Steele (1962) & 0.472 \\
\hline
\end{tabular}


